\title{
PENGARUH EKSTRAK BUAH TERONG BELANDA (SOLANUM BETACEUM) SEBAGAI ANTIOKSIDAN TERHADAP KADAR MALONDIALDEHIDA PADA TIKUS PUTIH (RATTUS NOVERGICUS) YANG DIINDUKSI $\mathrm{CCL}_{4}$
}

\author{
Aji Masbintoro', Sulistyo Mulyo Agustini ${ }^{2}$, Thontowi Djauhari NS ${ }^{3}$ \\ Fakultas Kedokteran, Universitas Muhammadiyah Malang \\ Jl. Bendungan Sutami 188 A Malang, 65145
}

Email : masbintoroaji@gmail.com

\begin{abstract}
ABSTRAK
Keadaan stres oksidatif dapat memicu peroksidasi lipid yang menghasilkan MDA sebagai indikator. Ekstrak terong belanda sebagai antioksidan dapat meredam dampak radikal bebas dan menurunkan kadar MDA. Metode Penelitian True Experiment dengan post test only group design yang terdiri 5 kelompok secara acak, masing-masing kelompok terdiri dari 5 hewan coba dan diberikan perlakuan selama 9 hari. Kelompok kontrol negatif, kelompok kontrol positif, perlakuan 1 (100 mg/ $\mathrm{kg} / \mathrm{BB}), 2$ (200 mg/kg/BB) dan 3 (300 mg/kg/BB). Kelompok perlakuan 1,2 dan 3 diberi induksi $\mathrm{CCl}_{4}$ pada hari ke 9. Hasil uji One Way Anova didapatkan nilai signifikansi $(0,002)$ kurang dari p $(0,05)$, yang berarti ada perbedaan yang bermakna antara kelompok kontrol dan kelompok perlakuan. Hal ini dikarenakan terong belanda memiliki kandungan fenol, flavonoid, antosianin dan karotenoidyang cukup tinggi yang dapat menghambat proses stres oksidatif. Ekstrak terong belanda sebagai antioksidan dapat menurunkan kadar MDA darah tikus yang diinduksi $\mathrm{CCl}_{4}$
\end{abstract}

Kata kunci : Stres oksidatif, ekstrak terong belanda, MDA darah

\begin{abstract}
Oxidative stress induces the peroxidation of lipid, which produces $M D A$ as an indicator. Extract tamarillo as an antioxidant can reduce the effects of free radicals and MDA levels. Research method in this experiment is True Experiment with Post Test-Only Group Design that consists 5 random groups. Each of the group consists of 5 experimental animals and are given a treatment for 9 days. The negative control group without any treatments, the positive control group, treatment 1 (100 mg/ kg/ bw), 2 (200 mg/ kg/ bw) and 3 (300 $\mathrm{mg} / \mathrm{kg} / \mathrm{bw})$. The treatment groups of 1, 2 and 3 were administered the induction of CCI4 on the 9th day. The result of One Way Anova showed the significant value (0,002) which is lower than p-value (0,05). It means that there is significant difference between control and treatment group. This is because Tamarillo contains high enough phenol, flavonoids, anthocyanins and carotenoids that can inhibit oxidative stress process. Tamarillo extract as an antioxidant can reduce MDA levels in the blood of male white mice induced by CCI4.
\end{abstract}

Key Words : Oxidative Stress, extract Tamarillo, MDA of blood 


\section{PENDAHULUAN}

MDA merupakan salah satu penanda stres oksidatif yang reliabel berdasarkan hasil penelitian BOSS (Biomarker Oxidative Stress Study) tahun 2002 (Donne et al., 2006). MDA merupakan salah satu biomarker yang paling baik dan dapat diandalkan sebagai pendeteksi stress oksidatif (lipid peroksidase) dan digunakan selama bertahun-tahun (Grotto et.al, 2009).

Stres oksidatif merupakan suatu keadaan dimana jumlah radikal bebas dalam tubuh lebih tinggi dari jumlah antioksidan. Stress oksidatif menginduksi peroksidasi membran lipid yang dapat menimbulkan perubahan struktur biologis membran sel (Atiqah, 2014).

Karbontetraklorida $\left(\mathrm{CCl}_{4}\right)$ merupakan bahan yang sangat reaktif yang dapat menyebabkan gangguan membran intraseluler dan kerusakan sel (Repotto, 2012). Pemberian $\mathrm{CCl}_{4}$ dapat menyebabkan peningkatan pembentukan peroksidasi lipid sehingga terbentuk produk akhir yaitu MDA dalam darah (Abmed, 2013).

Antioksidan secara alami bisa didapatkan dari makanan dan tumbuhan. Senyawa antioksidan adalah suatu inhibitor yang digunakan untuk menghambat autooksidasi (Sayuti, 2015). Tumbuhan obat dipertimbangkan karena efektifitasnya dan keamanan dalam penggunaanya. Tumbuhan obat yang mengandung banyak antioksidan flavonoid, fenolik dapat mencegah proses oksidasi. Antioksidan juga telah digunakan untuk mencegah proses peroksidasi lipid (Kaur, 2014).

Terong belanda di Indonesia dikenal dengan nama terong menen dan banyak dijumpai di Sumatra Utara (Asvita, 2016). Ekstrak etanol terong belanda memiliki kandungan phenolic dan flavonoid. Ekstrak etanol terong belanda memiliki aktivitas antioksidan terbesar dibandingkan tomat cherry kuning, tomat cherry merah dan buah tomat (Atiqah,2014).

\section{METODE}

\section{Jenis Penelitian}

Penelitian ini menggunakan rancangan penelitian eksperimental dengan Post Test Omly Control Group Design dengan tujuan mengetahui pengaruh ekstrak terong belanda terhadap kadar malondialdehida darah tikus putih yang diinduksi $\mathrm{CCl}_{4}$. Penelitian dilakukan di Laboratorium
Biomedik Fakultas Kedokteran Universitas Muhammadiyah Malang. Pembuatan Ekstrak Terong Belanda

Buah terong belanda (Solanum betaceum) dicuci bersih, kemudian dipotong-potong dan dikeringkan menggunakan oven. Terong belanda yang telah kering kemudian diblender hingga menjadi serbuk halus. Serbuk ini selanjutnya direndam dengan larutan etanol $70 \%$ selama $3 \times 24$ jam. Filtrat hasil perendaman kemudian dikumpulkan dan selanjutnya dilakukan evaporasi menggunakan rotary vacuum evaporator untuk mendapatkan ekstrak murni dari buah terong belanda.

Pemberian Ekstrak, Perlakuan dan Pemeriksaan

Tikus terlebih dahulu diaklimatisasi selama 7 hari untuk penyesuaian dengan lingkungan baru. Hewan coba dibagi menjadi 5 kelompok, yaitu kelompok K (+), kelompok K(-), dan 3 kelompok perlakuan (P1, P2, dan P3). Kelompok P1, P2 dan P3 masing-masing diberikan ekstrak terong belanda sebanyak $100 \mathrm{mg} / \mathrm{kgBB}, 200 \mathrm{mg} / \mathrm{kgBBdan} 300$ $\mathrm{mg} / \mathrm{kgBB}$ selama 8 hari. Selanjutnya seluruh kelompok diinduksi dengan $\mathrm{CCl}_{4}$ secara intraperitonial sebanyak $500 \mathrm{mg} / \mathrm{kgBB}$ pada hari ke sembilan kecuali kelompok kontrol negatif.

Jaringan darah tikus diambil pada hari ke 9 dengan cara pembedahan. Darah yang telah diambil kemudian diukur kadar MDA nya menggunakan metode TBARS (Thiobarbituric Acid Reactive Substance) (Kim, 2015).

\section{Perhitungan Kadar MDA Darah}

Kadar MDA darah tikus dihitung menggunakan metode TBARS. Mula-mula $1 \mathrm{ml}$ plasma darah ditambahkan dengan 10\% TCA. Setelah itu disentrifus dengan kecepatan 3000rpm selama 15 menit. Kemudian larutan TBA 0,65\% dicampurkan dalam $\mathrm{HCl} 0,25 \mathrm{~N}$. Setlah itu dicampurkan dan dipanaskan dengan suhu $95^{\circ} \mathrm{C}$ menggunakan waterbath. Setelah dingin ditambahkan dengan n-butanol. Kemudian disentrifus kembali dengan kecepatan 3000rpm selama 3 menit dan diambil supernatannya. Setelah itu dilakukan pengukuran dengan spektrofotometer UV dengan panjang gelombang $542 \mathrm{~nm}$ (Kim, 2015). 


\section{HASIL DAN PEMBAHASAN}

Rata-rata hasil pengukuran MDA dalam plasma tikus disajikan pada tabel 1 .

\begin{tabular}{|l|c|c|c|c|c|c|}
\hline \multirow{2}{*}{$\begin{array}{c}\text { Kelomp } \\
\text { ok }\end{array}$} & \multicolumn{5}{|c|}{ Ulangan } & Rata- \\
\cline { 2 - 6 } rata \\
\hline K- & 1 & 2 & 3 & 4 & 5 & \\
\hline P1 & 9,46 & 6,11 & 6,41 & 5,54 & 6,70 & 6,04 \\
\hline P2 & 6,41 & 7,69 & 7,78 & 8,40 & 9,80 & 8,75 \\
\hline P3 & 6,43 & 5,79 & 6,68 & 6,54 & 8,40 & 6,76 \\
\hline K+ & 10,42 & 9,59 & 7,38 & 9,96 & 10,26 & 9,52 \\
\hline
\end{tabular}

Tabel 1. Rata-rata kadar MDA plasma tikus

Berdasarkan tabel 1 dapat diketahui bahwa nilai rata-rata kadar MDA darah tikus normal (K) adalah sebesar $6,04 \mathrm{nmol} / \mathrm{ml}$. Sedangkan pada perlakuan tikus dengan induksi $\mathrm{CCl}_{4}(\mathrm{~K}+)$ nilai rata-rata kadar MDAnya sebesar $9,52 \mathrm{nmol} / \mathrm{ml}$. Pada perlakuan 1 (P1) dengan $100 \mathrm{mg} / \mathrm{kgBB}$ dosis ekstrak buah terong belanda, nilai kadar MDA dalam darah tikus mengalami penurunan menjadi $8,75 \mathrm{nmol} / \mathrm{ml}$. Kemudian pada perlakuan 2 (P2) dengan $200 \mathrm{mg} / \mathrm{kgBB}$ dosis ekstrak terong belanda, nilai rata- rata MDA darah tikus adalah sebesar 7,61 nmol/ml dan pada perlakuan ketiga (P3) dengan 300mg/ $\mathrm{kgBB}$ dosis ekstrak nilai ratarata kadar MDA yaitu sebesar $6,76 \mathrm{nmol} / \mathrm{ml}$.

Hasil uji analisis statistik One Way ANOVA menunjukkan signifikansi $(\mathrm{P})$ sebesar 0.000 . Nilai $\mathrm{P}$ $<0.05$. Hal ini mengindikasikan adanya pengaruh yang bermakna antara pemberian ekstrak buah terong belanda (Solanum betaceum) terhadap kadar $\mathrm{MDA}$ dalam darah tikus yang diinduksi $\mathrm{CCl}_{4}$.

Hasil uji Post Hoc Multiple Comparisons dengan metode Bonferroni menunjukkan adanya perbedaan yang nyata $(\mathrm{P}<0.05)$ antar perlakuan seperti yang terlihat pada tabel 2 .

Tabel 2 Hasil Uji Bonferroni rata-rata kadar MDA darah

\begin{tabular}{|l|c|c|}
\hline \multicolumn{1}{|c|}{$\begin{array}{c}\text { Kelompok } \\
\text { Perlakuan }\end{array}$} & N & $\begin{array}{c}\text { Rata-rata } \pm \\
\text { SD }\end{array}$ \\
\hline $\begin{array}{l}\text { dosis } 300 \mathrm{mg} / \mathrm{kgBB} \\
(\mathrm{P} 3)\end{array}$ & 5 & $8,75^{\mathbf{a}}$ \\
\hline dosis $200 \mathrm{mg} / \mathrm{kgBB}$ & 5 & $7,61^{\text {ab }}$ \\
\hline $\begin{array}{l}\text { dosis } 100 \mathrm{mg} / \mathrm{kgBB} \\
(\mathrm{P} 2)\end{array}$ & 5 & $6,76^{\mathbf{b c}}$ \\
\hline Kont rol positif & 5 & $9,52^{\mathrm{c}}$ \\
\hline
\end{tabular}

Keterangan: Notasi yang berbeda menunjukkan perbedaan yang signifikan

Tabel diatas menunjukkan bahwa pemberian dosis ekstrak terong belanda sebesar $100 \mathrm{mg} / \mathrm{kgBB}$ tidak berbeda secara nyata dengan kontrol positif (tanpa pemberian ekstrak). Sedangkan dosis $100 \mathrm{mg} / \mathrm{kgBB}$ juga tidak berbeda secara nyata dengan perlakuan dosis $200 \mathrm{mg} / \mathrm{kgBB}$. Begitu pula dengan dosis $200 \mathrm{mg} / \mathrm{kgBB}$ yang berbeda secara nyata dengan kontrol positif namun tidak berbeda nyata dengan perlakuan $300 \mathrm{mg} /$ $\mathrm{kgBB}$. Kemudian perlakuan dosis $300 \mathrm{mg} / \mathrm{kgBB}$ berbeda secara nyata dengan perlakuan kontrol positif. Berdasarkan hasil uji Bonferroni ini, diketahui bahwa dosis ekstrak sebanyak $200 \mathrm{mg} / \mathrm{kgBB}$ dan $300 \mathrm{mg} / \mathrm{kgBB}$ dapat menurunkan kadar MDA dalam darah tikus yang diinduksi $\mathrm{CCl}_{4}$ secara bermakna.

Hasil uji one way anova dan bonferroni didukung oleh penelitian Oktarini (2014) mengenai uji antioksidan biji terong belanda terhadap kadar MDA darah menunjukkan hasil uji One Way Anovanya didapatkan nilai signifikansi $\mathrm{p}<0,05$ antara kontrol dan perlakuan (dosis ekstrak biji terong belanda $200 \mathrm{mg} / \mathrm{kgBB}$ dan vitamin E $100 \mathrm{mg} / \mathrm{kgBB}$ ). Sedangkan dalam uji benferroni dibandingkan dengan penelitian Oktarini (2014) memiliki nilai dosis yang sama yaitu $200 \mathrm{mg} / \mathrm{kgBB}$. Perbedaan penelitian ini dengan Oktarini (2014) yaitu dalam penelitian ini menggunakanekstrak keseluruhan terong belanda, sedangkan Oktarini (2014) hanya menggunakan ekstrak biji terong belanda. Namun penggunaan ekstrak secara keseluruhan terong belanda didukung oleh Hassan (2013) bahwa kandungan flavonoid terong belanda lebih tinggi berada dalam kulit terong belanda dari pada didalam daging buah. Sedangkan kandungan antocianin berada dalam kedua-duanya yaitu dalam kulit dan daging buah. Kandungan karotenoid lebih tinggi ada di daging buah. Oleh karena itu peneliti dalam hal ini mengambil ekstrak terong belanda secara keseluruhan.

Tabel uji korelasi Pearson antara dosis ekstrak terong belanda dan hasil MDA darah menunjukkan nilai sig (2-tailed) $+0.000, \mathrm{p}<0.001$ dengan nilai $\mathrm{r}(-0.776)$. Hal ini menunjukkan nilai Pearson correlation sangat bermakna dan arahnya negatif (-), yaitu semakin besar dosis ekstrak buah terong belanda menyebabkan semakin rendah hasil MDA dalam darah tikus. Hasil interpretasi nilai ini 
sejalan dengan hasil penelitian Atiqah (2014) bahwa kekuatan aktifitas penangkalan radikal bebas oleh terong belanda dengan nilai EC50 sebesar 44,25.

Penurunan kadar MDA pada perlakuan dosis $200 \mathrm{mg} / \mathrm{kgBB}$ dan $300 \mathrm{mg} / \mathrm{kgBB}$ dikarenakan ekstrak buah terong belanda mengandung beberapa senyawa yang diketahui bersifat antioksidan. Hasil penelitian Hassan et al., (2013) menyebutkan bahwa buah $S$. betaceum memiliki kandungan fenol, flavonoid, antosianin dan karotenoid yang memiliki aktivitas antioksidan. Antioksidan bereaksi dengan radikal bebas dengan cara mengurangi konsentrasi oksigen, mencegah pembentukan singlet oksigen yang reaktif, mencegah inisiasi rantai pertama dan menangkap radikal primer, memutus rantai hidroperoksida dan mendekomposisi produkproduk primer radikal menjadi senyawa non radikal (Astuti, 2014).

Uji regresi digunakan untuk mengetahui besar pengaruh antara dosis ekstrak buah terong belanda terhadap kadar MDA tikus dengan induksi $\mathrm{CCl}_{4}$. Berdasarkan hasil uji regresi pada tabel diatas, dapat diketahui nilai signifikansi $=0.000$ (lampiran 4), yang berarti $\mathrm{P}<0.05$ sehingga uji regresi dikatakan signifikan. Koefisien determinasi didapatkan Adjusted $\mathrm{R}^{2}=0.580$ yang menyatakan nilai pengaruh dari pemberian ekstrak buah terong belanda (Solanum betaceum) terhadap kadar MDA tikus sebesar $58 \%$, sedangkan sisanya sebesar $42 \%$ disebabkan oleh faktor-faktor lain yang mempengaruhi seperti antioksidan primer, reduced glutathione (GSH), dan katalase yang berperan langsung dalam menghambat radikal bebas (Hwang et al., 2011).

\section{KESIMPULAN}

Ekstrak buah terong belanda (Solanum betaceum) berpengaruh dapat menurunkan kadar malondialdehida (MDA) darah tikus putih jantan (Rattus norvegicus) strain wistar yang diinduksi karbon tetraklorida $\left(\mathrm{CCl}_{4}\right) \cdot \mathrm{CCl}_{4}$ dapat meningkatkan kadar MDA dengan $6,04 \mathrm{nmol} / \mathrm{ml}$ menjadi $9,52 \mathrm{nmol} /$ ml.Dosis efektif ekstrak buah terong belanda (Solanum betaceum) sebesar $200 \mathrm{mg} / \mathrm{kgBB}$.

\section{DAFTAR PUSTAKA}

Ahmed, Hanaa, Helal Abu El Zahab, Gamia Alswiai, 2013,Purification of antioxidant protein isolated from Peganum harmala and its protective effect against $\mathrm{CCl}$,Turk $J$ Biol (2013) 37: 39-48.

Asvita, Silvia Mara, Berawi, Khairun Nisa, 2016. Efektivitas ektrak terong belanda untuk menurunkan kadar glukosa dan kolesterol darah pada pasien obesitas. Majority.vol 5 (1), 102 .

Atiqah, Noor, Maisarah, A. M., dan Asmah R, 2014,Comparison of antioxidant properties of tamarillo (Cyphomandra betacea), cherry tomato (Solanum bycopersicum var. cerasiform) and tomato (Lyopersicon esculentum), International Food Research Journal, 21 (6): 2355-2362.

Donne, Isabella Danne, Ranieri Rossi, Roberto Colombo, Daniela Giustarini, dan Aldo Mizani, 2006, Biomarker of Oxidative Damage in Human Disease, J. Clinc. Chem, 52(4): 601-623.

Grotto, D., G. R. Barcelos, J. Valentini, L. M. Antunes, J. P. Angeli and S. C. Garcia, 2009, Low Level of Methilmercury Induce DNA Damage in Rats: Protective Effets of Selenium, Arch Toxicol, 83: 249-5.

Hasan SHA \& Bakar MFA, 2013. Antioxidative and Anticholinesterase Activity of Cypomandra betaceae Fruits. Kota Kinabalu, Sabah, Malaysia, Hindawi Publishing Corporation The Scientic World Journal Volume 2013,Article ID 278071.

Kaur, S., dan Mondal, P. 2014. Study of Total Phenolic and Flavonoid Content, Antioxidant Activity, and Antimicrobial Properties of Medicinal Plants,Journal of Microbiology and Experimentation 1 (1) : 1-6.

Kim, Dong Hyun, Seung Jun Kwack, Kyung Sik Yoon, Jin Shil Choi, dan Byung Mu Lee, 2015, A Superior Oxidative Biomarker Compared to Malondialdehyde and Carbonyl Content Induced by Carbon Tetrachloride in Rats, Journal of Toxicology and Environmental Health, 1-12.

Oktarini, Ni Wayan, Ni Made Puspawati dan I Made Dira, 2014, Aktivitas flavanoid Ekstrak Biji Terong Belanda (Solanum betaceum) dalam Menghambat Reaksi Peroksidasi Lemak pada Plasma Darah Tikus Wistar,Jurnal Penelitian Fakultas MIPA, Universitas Udayana. 
42 VOLUME 12 NOMOR 1 JUNI 2016

Repetto, Marisa 2012. Lipid Peroxidation. Croatia . InTech. ISBN 978-953-51-0716-3.

Sayuti, Kusuma, Yenrina, Rina. 2015. Antioksidan alami dan sintetik. Padang. Andalas university press. ISBN 978-602-8821-97-1. 